\title{
Construction and validation of digital education resources for the health and safety of workers
}

\author{
Construção e validação de recursos educativos digitais \\ para a saúde e segurança do trabalhador \\ Construcción e validación de recursos educativos digitales \\ para la salud y seguridad de los trabajadores
}

\author{
Silvana Aline Cordeiro Antoniolli $i^{a, b}$ \\ Ana Paula Rossato Assenato ${ }^{c}$ \\ Bárbara Rodrigues Araújoc \\ Vitória Eugênia da Costa Lagranha ${ }^{c}$ \\ Luccas Melo de Souzad \\ Adriana Aparecida $\mathrm{Paz}^{\mathrm{a}, \mathrm{d}}$
}

\section{How to cite this article:} Antoniolli SAC, Assenato AAR, Araújo BR, Lagranha VEC, Souza LM, Paz AA. Construction and validation of digital education resources for the health and safety of workers. Rev Gaúcha Enferm. 2021;42:e20200032. doi: https://doi. org/10.1590/1983-1447.2021.20200032 a Universidade Federal de Ciências da Saúde de Porto Alegre (UFCSPA). Programa de Pós-Graduação em Enfermagem. Porto Alegre, Rio Grande do Sul, Brasil.

b Prefeitura Municipal de Florianópolis. Secretaria Municipal de Saúde de Florianópolis. Florianópolis, Santa Catarina, Brasil.

Universidade Federal de Ciências da Saúde de Porto Alegre (UFCSPA). Curso de Bacharelado em Enfermagem. Porto Alegre, Rio Grande do Sul, Brasil.

d Universidade Federal de Ciências da Saúde de Porto Alegre (UFCSPA). Departamento de Enfermagem. Porto Alegre, Rio Grande do Sul, Brasil.

\section{ABSTRACT}

Objectives: To build and validate the content of digital educational resources (DERs) for the promotion of health and safety for professionals working in Primary Health Care (PHC).

Methods: Methodological study consisting of two stages: the first describes the phases of the construction of DERs; and the second validated the content of DERs by a Committee of Experts that used the Instrument for Validating Educational Content in Health (IVECH) and applied the Content Validity Index (CVI).

Results: Seven storyboards have been built in MP4 obtaining the overall CVI from 0.84 to 0.96 . In relation to "objectives", the CVI ranged from 0.84 to 0.95 ; in "structure/presentation", from 0.91 to 0.99 ; and in "relevance", from 0.81 to 0.95 .

Conclusions: The seven DERs are validated products that can be used for permanent health education on health and safety at work of PHC professionals.

Keywords: Education, continuing. Occupational health. Primary health care. Instructional film and video. Nursing.

\section{RESUMO}

Objetivos: Construir e validar o conteúdo de recursos educativos digitais (REDs) para a promoção da saúde e segurança no trabalho de profissionais que atuam na Atenção Primária à Saúde (APS).

Métodos: Estudo metodológico constituído por duas etapas: 1) descreveu as fases da construção dos REDs; e 2) validou o conteúdo dos REDs por um Comitê de Especialistas, utilizando o Instrumento de Validação de Conteúdo Educativo em Saúde e aplicou o teste de Índice de Validade de Conteúdo (IVC).

Resultados: Construíram-se sete REDs, em formato de vídeo MP4. Estes REDs alcançaram o IVC global de 0,88 a 0,96. No domínio "objetivos" o IVC variou de 0,84 a 0,95; em "estrutura/apresentação" de 0,91 a 0,99; e"relevância" de 0,81 a 0,95.

Conclusões: Os REDs são produtos validados que podem ser utilizados para a educação permanente em saúde dos profissionais da APS acerca da saúde e segurança no trabalho.

Palavras-chave: Educação continuada. Saúde do trabalhador. Atenção primária à saúde. Filme e vídeo educativo. Enfermagem.

\section{RESUMEN}

Objetivos: Elaborar y validar el contenido de recursos educativos digitales (REDs) para la promoción de la salud y seguridad en trabajo para los profesionales que actúan en la Atención Primaria a la Salud (APS).

Métodos: Estudio metodológico en dos etapas: 1) describe las etapas de la construcción de los REDs; y 2) validó el contenido de lo REDs por un Comité de Expertos utilizando el Instrumento de Validación de Contenido Educativo en Salud y aplicó la prueba del Índice de Validez de Contenido (CVI).

Resultados: Fue construido siete REDs, en video MP4, que alcanzaron el CVI global de 0,88 a 0,96. En el dominio "objetivos" el CVI varió de 0,84 a 0,95; en "estructura/presentación" de 0,91 a 0,99; y"relevancia" de 0,81 a 0,95.

Conclusiones: Los REDs son productos validados que se pueden utilizar para la educación permanente de los profesionales de la APS sobre salud y seguridad en trabajo.

Palabras claves: Educación continua. Salud laboral. Atención primaria de salud. Película y video educativos. Enfermería. 


\section{口INTRODUCTION}

Primary Health Care (PHC) is the organizer of services and the main gateway for users to the Unified Health System (SUS). The user's first contact with health services occurs due to low technological density. The central principles of SUS in health care for the Brazilian population are universal access, comprehensive care and equity in actions, which are fundamental in the context of $\mathrm{PHC}^{(1)}$.

In this health care scenario, professionals who develop strategic actions for user care in health units are exposed to various occupational risks, such as: physical, chemical, biological, ergonomic, accidents and psychosocial(2). These risks permeate the work of all PHC workers, being differentiated when dealing, for example, with home visits, or with specific activities of professionals in the health unit. During these activities, the professional may face factors such as violence, which generate emotional exhaustion, in addition to the physical exhaustion already expected due to exposure to the environment and teamwork ${ }^{(3)}$. Sometimes, in practice, they eventually remember the safety guidelines at work to avoid possible situations that can be harmful to physical and mental health ${ }^{(4)}$. The complexity of an injury to the health of the professional due to non-compliance with safety at work can trigger pathological processes that require personal, family, social, labor and institutional adaptations, which can be unfavorable(5).

Permanent health education (PHE) can rescue this technical-scientific knowledge to promote health and safety at work for PHC professionals ${ }^{(6)}$. The approach to these contents generally occurs in academic training or when professionals are admitted to institutions. However, the demand for activities in the health units makes it difficult for professionals to use the moment of PHE to discuss their own health and safety in the context of work. In view of the above, the need to build PHE activities on promoting health and safety at work for professionals working in PHC was identified. As an education strategy, we opted for the use of active methodology with the use of short-duration digital educational resources (DERs), which can be used as triggers of a problematization process (action-reflection-action) in asynchronous moments. Resources can be created using current technology, using different software, adding dynamism, involvement and creativity to develop and adapt content ${ }^{(7-8)}$.

DERs provide general and specific information, and, when constructed from under an active methodology perspective, they encourage the participant to take the lead. However, in order to expand and validate the use of DERs, the target audience must validate the educational material before its use. The content can be considered valid when it is able to actually evaluate its objective. The validation can occur through three methods: content validation, validation related to a criterion and construct validation ${ }^{(9)}$.

Content validation seeks to ensure the relationship between theory and practice, through the critical and reflective contribution of an Expert Committee. It is a process that assesses its representativeness by adequately addressing the universe it proposes, in addition to measuring or addressing the absence of unnecessary elements ${ }^{(9-12)}$.

In view of the importance of preparing PHE on promoting health and safety at work for professionals working in $\mathrm{PHC}$ and the need to prepare materials with technical and scientific quality, the following research question emerged: "How to build and validate the content of DERs for the promotion of health and safety at work for professionals working in PHC?"

In this sense, the objective of this study was to build and validate the content of DERs for the promotion of health and safety at work by professionals working in PHC.

\section{METHODS}

This is a methodological study, consisting of two distinct stages, the first of which describes the stages of the construction of the DREs, and the second involved the content validation by an Expert Committee. Meetings were held by the executive team to organize the logistics of the two stages that included the construction and validation of the product content.

In stage 1, of building the DERs, the scenario involved the different spaces, at the Federal University of Health Sciences of Porto Alegre (UFCSPA, or Universidade Federal de Ciências da Saúde de Porto Alegre), for the production of knowledge and the elaboration of products, using equipment, software and materials for publishing. Three researchers and four scientific initiation fellows took part as volunteers. The phases of this stage were: a) identification of the technical-scientific production on health and safety at work associated with the experiences in the area by the researchers, b) definition of themes, c) storyboard development (as a draft that helps in the narrative construction and organization of content, highlighting the sequence and composition of scenes, meaning a prototype of the technological production of the final product), d) elaboration of the technical file, e) publishing DERs in video format, and f) availability of DERs as a final product for public and free access.

In step 2, for content validation of the DERs, an Expert Committee was formed, composed of seven specialist professionals. The literature recommends the participation of six to twenty specialists and the snowball method was chosen as a recruitment ${ }^{(13-14)}$. It was defined that the Expert 
Committee would be comprised of professionals with at least three different characteristics: a) a university professor with a degree in the area of Health Science, with a minimum degree of Master and who accompanies students in PHC, b) a health professional with PHC practice, c) a professional in the area of health and safety at work. To be included in the Expert Committee, professionals should have at least two years of experience in their fields and not be on vacation or on either sick or maternity leave.

Initially, the first two specialists were recruited through two different simple random draws in the Nursing Department (twelve teachers met the criteria) and Public Health Department (five teachers) at UFCSPA. The intention to elect professors from these Departments as specialists in content validation was due to their performance as nurses and family and community doctors. Each participating specialist appointed three new specialists for content validation, according to the eligibility criteria. 17 invitations were sent by e-mail to the nominees to comprise the Committee and, of these, seven actually did. Among those who did not make up the Committee, the following justifications were listed: one did not participate because he claimed that he did not meet the study's eligibility criteria, another had an invalid email address, a third party recommended himself and did not recommend other professionals, and seven other invited experts did not return the invitation during the data collection period. As there was no indication to the project of a professional in the area of health and safety, selected through the snowball method, it was necessary to indicate that specialist according to convenience.

To validate the DERs' content, the instrument for data collection called "Questionnaire for content validation of Digital Educational Resources," semi-structured and self-applied. In this questionnaire, the Instrument for Validation of Educational Content in Health $(\mathrm{VECIH})^{(12)}$ was incorporated, consisting of three domains and eighteen questions, in which the agreement on the objective (purposes, goals or purposes), structure/presentation (organization, structure, strategy, coherence and sufficiency) and relevance (significance, impact, motivation and interest) is measured. This instrument has the capacity to validate the content of educational materials in health, when for the use of health professionals with higher education who wish to build and validate educational content for any target audience.

The VECIH uses a Likert scale with a score ranging from zero to two (0 - disagree, 1 - partially agree, and 2 - totally agree). Also, at the end of the questionnaire, a qualitative space is included to record criticisms or suggestions for the qualification of DERs, with this process being indicated by some authors as a means to obtain a qualitative assessment ${ }^{(9)}$.
The Free and Informed Consent Form (FICF) and the questionnaire were edited in the Google Forms ${ }^{\oplus}$ format, containing the electronic addresses of each DER for viewing by the specialist, all of which are aggregated in a single electronic address. Data collection took place from May to July 2019, with an informative invitation about the period made available to participate in the study (which should take up to ten days), the estimated time for the activity (around 90 minutes to view the DERs and completing the instrument) and the electronic address for accessing the instrument. Seven experts participated, who agreed to participate in the study by clicking "yes" for the online informed consent form, available on the first screen of Google Forms ${ }^{\circledR}$. None of the specialists left the questionnaire undone.

The data generated by the responses of the specialists in Google Forms ${ }^{\oplus}$ were deposited in the Google Sheets ${ }^{\oplus}$ spreadsheet, being organized in the form of a database, then exported to the Statistical Package Social Science ${ }^{\varpi}$ and analyzed by descriptive and analytical statistics.

The content validity index (CVI) was used, characterized by being an analytical method that measures the proportion or percentage of judges/specialists who are in agreement on certain aspects of the instrument and its items, therefore, it expresses the rate of agreement obtained by the experts' evaluation. To calculate the CVI in this VECIH, the Likert- type scale varies from 0 to 2 points ${ }^{(12)}$. Only the sum of the answers "fully agree" (option 2) was considered for this calculation, which was divided by the sum of all answers, being consistent when $\geq 0.80^{(12)}$. The CVI was assessed by domain (objective, structure/presentation and relevance) and general, according to the VECIH, and this instrument was also submitted to internal consistency analysis by Cronbach's Alpha ( $a \geq 0.700)$ (12). Internal consistency is related to the ability of items of a same dimension to be consistent and to relate to the proposed measurement ${ }^{(15)}$.

The critiques and/or recommendations for improving the DERs were organized and named by the letter " $E$ " (for especialista, or specialist in Portuguese) and added to the number included in the order of the Google Sheets ${ }^{\circledR}$ database ("E1", "E2", ..."E7").

The study was approved by the UFCSPA Research Ethics Committee (CEP) (opinion No.3,035,981) and by the co-participant, by the CEP of the Municipal Health Secretariat of Porto Alegre (opinion No.3,207,144).

\section{RESULTS}

The DERs were built from the references of the Ministry of Health, the Ministry of Labor and Employment and the updated scientific literature addressing health and safety at 
work in PHC. The themes were defined by the technical-scientific production of the area associated with the professional experiences of the researchers. The organization of the DERs was proposed in order to allow a better understanding of the topic. However, the possibility of being used in a random sequence by professionals is not excluded.

With the definition of themes and ordering, the seven DERs on health and safety at work in PHC are presented, entitled: DER1 - Health and safety at work in PHC, DER2 Occupational risks in PHC, DER3 - Occupational diseases in PHC, DER4 - Regulatory Standard 32 (NR-32), DER5 - Personal Protection Equipment (PPE) and Collective Protection Equipment (CPE), RED6 - Accidents and incidents at work in PHC, and DER7 - Record of accidents and incidents at work in PHC.

The contents were organized and structured in their own storyboards and in a technical sheet for each resource. The technical file contained the title information of the resource, duration of the video in minutes and seconds, format of the technological production in MP4, size of the video document in megabytes, description as a syllabus of the approach to the theme, objectives of the video, content covered, tags (concept), identification of availability on social media, and email address of each DER. Microsoft ${ }^{\oplus}$ Power Point ${ }^{\oplus}$ visual presentation editor in slide show format ( ${ }^{*}$.ppsx) was used as storyboards. Then, images and vectors were included, extracted from public Internet research banks, for the use of free images and vectors, highlighting Dreamstime, Flaticon , Free Designer Files, Freepik, Pexels, Pinterest and Pngtree.

Narrations about the content of the subjects under study were added to each of the seven DERs, which were recorded by the researchers in the Moving Picture Experts Group (MPEG) 1/2 Audio Layer 3 (*.MP3) format. To finalize the product, we chose the format in Moving Picture Experts Group (MPEG)4 Part $14\left({ }^{*} . \mathrm{MP} 4\right)$, which was converted from the visual editor, becoming a video.

The total time spent in the construction of the technological products was 850 hours, over four months, by the members of the executing team, which resulted in the final visualization of all the DERs in 68 minutes and 38 seconds. Figure 1 gathers the first image of each of the seven DERs, providing information on the duration of each video and the size in Megabytes (MB). The DERs were stored in the Google Drive ${ }^{\circledast}$ repository, containing an email address for each resource and the QR Code. DERs are available for viewing and downloading, but do not allow editing and/or comments.

The Specialist Committee was made up of seven professionals, four professors from UFCSPA, two professionals who work in the health unit and one who works in the health and safety service in PHC. The specialists were exclusively female, with an average age of $43 \pm 6.3$ years. There was a predominance of nurses 6 (85.7\%), with a Ph.D. degree (42.8\%) and Post-Doctorate 1 (14.3\%), with the majority developing work activities in public institutions 5 (71.4\%). The most significant time of professional experience was that of a specialist with 30 years working in the health unit.

The validation process lasted 46 days, counting from the first invitation to the last completed evaluation. The DERs were validated by the $\mathrm{VECIH}$, which consists of three domains: objectives, structure/presentation and relevance of the educational product. The results obtained for the comparison of the global CVI and by domains, as well as the internal consistency (Cronbach's Alpha) of the DERs for health and safety at work in PHC are shown in Table 1.

All seven DERs reached agreement on both the global IVC and the three $\mathrm{VECIH}$ domains. Domain 1 (objectives) obtained a CVI variation from 0.84 to 0.95 , highlighting three DREs with a CVI of 0.95. In domain 2 (structure/presentation), the CVI ranged from 0.91 to 0.99 , obtaining the greatest agreement from specialists in RED7 - Record of accidents and incidents at work in PHC. The variation in domain 3 (relevance) was between 0.81 and 0.95 .

The global CVI of DERs varied from 0.88 to 0.96 , highlighting the greatest agreement in RED7 - Record of accidents and incidents at work in PHC. Regarding the general internal consistency test, Cronbach's Alpha, DER4 - Regulatory standards 32 (NR-32) had an internal reliability lower than that recommended (0.586); and DER6 - Accidents and incidents at work in PHC achieved the best internal reliability (0.916).

The DER1 - Health and safety at work in PHC obtained the full agreement on items in domain 1 (objectives) "provides reflection on the theme", and in domain 2 (structure/ presentation) "Language appropriate to educational material," "Correct information," and "Current topic". All other items and domains had a CVI of 0.73 to 0.92 . The experts' descriptive critique/recommendations were: replacement of the narration by another speaker (E1), improve the dynamics of content presentation to avoid focusing on reading the video and the tiring listening (E7), very well elaborated, pertinent and adequate resource, considering it didactically excellent (E1, E4 and E7), and the content covered has the potential to clarify doubts about the proposed theme (E7).

The full CVI in DRE2 occurred in four items: in domain 1 (objectives) "Adequate to the teaching-learning process" and in domain 2 (structure/presentation) "Language appropriate to educational material," "Logical sequence of ideas," and " Current theme." All other items and domains reached the $\mathrm{CVI}$, which ranged from 0.83 to 0.94 . Regarding the critique/ recommendations, it was mentioned that the dynamics presented is attractive, as it stimulates attention and interest (E1), content is excellent, interesting and appropriate 

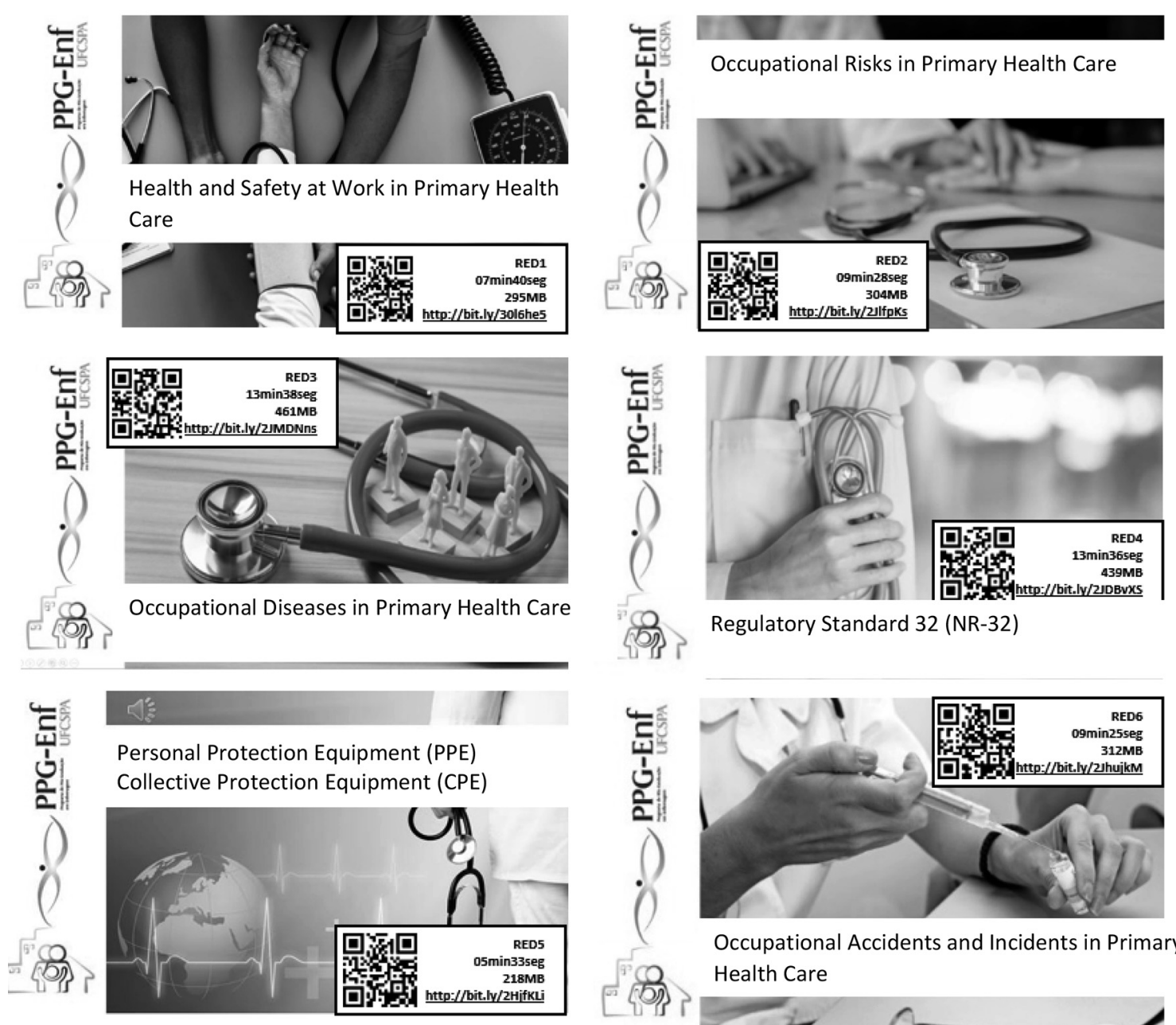

Occupational Accidents and Incidents in Primary Health Care

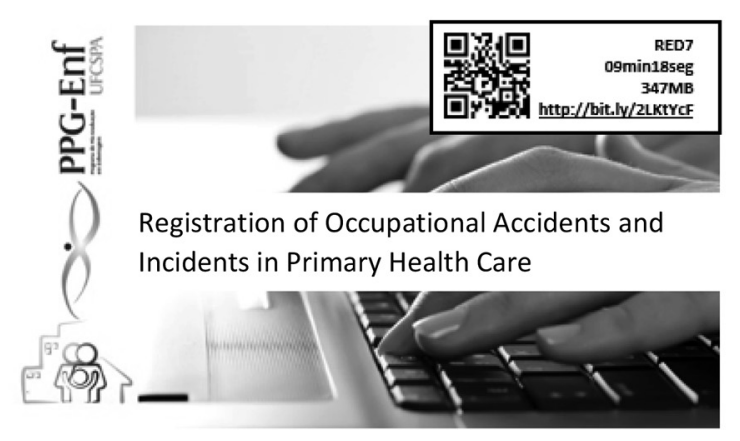

Figure1 - Digital educational resources for health and safety at work in Primary Health Care Source: UFCSPA. Nursing Graduate Program, 2019.

to the proposed theme (E4 and E7), there is an increased time between one screen and another in the video (E2), some screens have many texts (E5), there are overlapping lines between some screens (E4 and E5), narration should approach more than what is written on the screen (E5), and a fixation exercise should be added to the content to facilitate learning (E7).
In DER3 - Occupational diseases in PHC, the full CVI occurred in domain 1 (objectives) in the item "Encourages behavior change," in domain 2 (structure/presentation) in the items "Correct information," "Objective information," and "Current topic," and in domain 3 (relevance) in the item "Contributes to knowledge in the field." All other items and domains reached the CVI from 0.81 to 0.92 , except for the 
Table 1 - Global content validity index, by domains and the internal consistency of digital educational resources for health and safety at work in Primary Health Care. Porto Alegre, Rio Grande do Sul, Brasil, 2019

\begin{tabular}{|c|c|c|c|c|c|}
\hline DERs * & $\begin{array}{l}\text { Domain } 1 \text { - } \\
\text { Objectives } \\
\text { CVI }^{+}\end{array}$ & $\begin{array}{c}\text { Domain } 2 \text { - } \\
\text { Structure/Presentation } \\
\mathrm{CVI}^{\dagger}\end{array}$ & $\begin{array}{c}\text { Domain } 3 \text { - } \\
\text { Relevance } \\
\mathrm{CVI}^{+}\end{array}$ & Global CVI $^{+}$ & $\begin{array}{l}\text { Global a } \\
\text { Cronbach }\end{array}$ \\
\hline RED1. & 0.84 & 0.91 & 0.92 & 0.89 & 0.847 \\
\hline RED2. & 0.88 & 0.94 & 0.92 & 0.91 & 0.907 \\
\hline RED3. & 0.92 & 0.92 & 0.81 & 0.88 & 0.744 \\
\hline RED4. & 0.95 & 0.94 & 0.89 & 0.93 & 0.586 \\
\hline RED5. & 0.95 & 0.96 & 0.95 & 0.95 & 0.858 \\
\hline RED6. & 0.92 & 0.91 & 0.86 & 0.90 & 0.916 \\
\hline RED7. & 0.95 & 0.99 & 0.95 & 0.96 & 0.812 \\
\hline
\end{tabular}

Source: Research data, 2019

Observations: ${ }^{*}$ DERs: Digital Educational Resources, ${ }^{+} \mathrm{CVI}$ : Content Validity Index.

item "Arouses interest in the theme" of domain 3 (relevance), which reached the CVI of 0.60 . The critique/recommendations are aimed at reducing the size of the video (E2), the increased time between screens (E2), presents reflection on the theme (E7), it could include the specific content of legislation to increase the visibility of the theme (E1), and bring practical situations to approach the theme (E2).

DER4 presented CVI with a full degree in domain 1 (objectives) in the items "Adequate to the teaching-learning process" and "Encourages behavior change," and in domain 2 (structure/presentation) in the items "Correct information," "Necessary Information," "Logical sequence of ideas" and "Current theme." All other items and domains reached the $\mathrm{CVI}$ with a range from 0.83 to 0.95 . The experts' critique/recommendations for this resource were: adequate and relevant approach to the worker's health (E1), there is increased time between video screens and the absence of some titles (E2), suggestion to share the content in two videos due to the density of the theme (E2), and bring common situations that occur in PHC in relation to NR-32.

In DER5 - Personal Protective Equipment (PPE) and Collective Protection Equipment (CPE), the CVI with a full degree was found in domain 1 (objectives) in the items "Contemplates proposed theme" and "Encourages behavior change," in domain 2 (structure/presentation) in the items "Correct information,","Objective information,"'Enlightening information," "Necessary information," "Logical sequence of ideas" and "Current theme," and in domain 3 (relevance) in the item "Contributes to knowledge in the area." All other items and domains reached the CVI with a range from 0.83 to 0.96 . The experts stated that they have a lot of content, which implies an increased time in the transition of video screens (E2), narration volume considered lower than in other videos (E7), an illustration about protective equipment with correct and wrong was suggested (E1), and the duration of the video is adequate to maintain concentration (E5).

The full CVI in DER6 was observed in domain 1 (objectives) "Contemplates proposed theme," and in domain 2 (structure/ presentation) "Language suitable for the target audience," "Correct information," Necessary information and "Current topic." All other items and domains presented the CVI, which ranged from 0.73 to 0.92 , demonstrating agreement with the product's content. The critique/recommendations were in relation to the size, the density of the text, and the increased time between screens (E2), the specific item "classification of gravity" is very dense (E1), differences in volume grading during the narration, gaps in the audio specifying the precise times for the correction and a request to qualify the speaker's diction (E4 and E7), the content was considered adequate and with clear flows (E1).

In DER7 - Record of accidents and incidents at work in $\mathrm{PHC}$, thirteen items of the $\mathrm{VECIH}$ reached the IVC with a full degree: domain 1 (objectives), in the items "Contemplates proposed theme,"'Adequate to the teaching-learning process" 
and "Clarifies doubts about the topic addressed," domain 2 (structure/presentation) in nine out of ten items: "Language suitable for the target audience," "Language appropriate to educational material," "Correct information," "Objective information," "Enlightening information," "Necessary information," "Logical sequence of ideas," "Current theme" and "Adequate text size" and domain 3 (relevance) in the item "Contributes to knowledge in the field." All other items and domains reached agreement, varying from 0.83 to 0.99 . The critique/recommendations showed very long content, increased time in the transition of screens and the need to improve the narrator's diction (E2 and E4).

\section{DISCUSSION}

The relevance of the approach to health and safety at work in PHC is fundamental to strengthen the work process in the context of PHC in Brazil. SUS progressively faces challenges due to socioeconomic conditions and significant inequalities in the population's access to health, as well as in the conditions of physical structure of health units and hiring/ dimensioning of Moving Picture Experts Group ${ }^{(1,4)}$ professionals.

The applicability of DERs in the PHC teams'teaching-learning process is related to the integrality of health care, which can be achieved by PHE actions ${ }^{(6,12)}$. It is believed that the implementation of educational actions, such as the construction and use of DERs in a context experienced and permeated by a critical-reflective process of discussing the factors that lead to the onset of incidents, accidents and illnesses at work, has the potential to promote safe and effective behaviors ${ }^{(3,5)}$.

The contents that subsidized the DERs reinforced several aspects of health and safety at work, such as the different exposure of PHC professionals, when it comes, for example, to carrying out home visits, in which they can face situations such as violence and unfavorable environmental conditions, with the ability to generate emotional and physical wear ${ }^{(2,4)}$. Therefore, knowing the work environment and discussing occupational conditions and risks is essential for the broad knowledge of safety, monitoring and control problems to avoid the process of occupational illness ${ }^{(3)}$.

The contents of the DERs were validated in order to improve their technical and scientific quality. The scientific literature reinforces that the use of DERs in health, when scientifically validated, can be used to strengthen the educational process of health professionals $s^{(7,12)}$.

The VECIH used in the content validation of DERs optimized this evaluation process. The items that made up domain 1 (objectives) are important, as they present the way in which the contents are organized, which enriches the teaching-learning process and facilitates the exchange of knowledge, ideas and experiences on a given topic $c^{(7,12,16)}$. In a study that validated the content of the storyboard presented for the construction of an educational video for the deaf about cardiopulmonary resuscitation, the $\mathrm{CVI}$ related to the objectives of the resource was $0.86^{(17)}$.

Domain 2 (structure/presentation) showed the congruence of structure, cohesion, organization, sufficiency, in addition to adequate language and content with consistency in view of the proposed objectives ${ }^{(12)}$. It is noteworthy that, in this domain, it was essential to maintain the focus on the proposed theme to facilitate the understanding and the logical sequence of the ideas that make up the topics, texts and screens of the DERs. Sufficiency was also shown to be relevant when being evaluated to avoid possible doubts about the contents covered ${ }^{(8,11,17)}$. Domain 3 (relevance) addressed the assessment of variables based on the degree of significance of the educational content and the ability to cause impact, motivation and/or interest ${ }^{(12)}$.

Full CVI occurred in different domains of all DERs, which is characteristic to studies with this design. Another study on video validation that addresses cardiorespiratory arrest for the deaf achieved similar results for full $\left.\mathrm{CV}\right|^{(17)}$.

In this study, Cronbach's alpha ranged from 0.586 to 0.916 for the internal consistency of the experts'responses. Similar values have been found in different investigations, as in a study that validated an educational game about sexuality for adolescents that presented Cronbach's alpha $(0.880)^{(15)}$. Expressive values were shown in the study on the construction and validation of educational material for the prevention of metabolic syndrome in adolescents, with Cronbach's alpha of 0.917 , being successfully validated by specialists ${ }^{(18)}$.

Critique/recommendations from experts contributed considerably to the qualification of DERs. It is believed that being open to receive critiques/recommendations allows the content to be reorganized in a constructive manner, as it adds technical and scientific quality ${ }^{(8,12)}$. The presentation of the seven products in video format emerged as a didactic proposal, so that the content approach was significant in the teaching-learning process for professionals in the context of $\mathrm{PHC}^{(8,19)}$.

When looking at the resource's central theme, it is clear that health and safety at work in PHC has the ability to provoke critical reflection on the possible events that trigger injuries and that can be avoided in daily practice to promote individual and collective health. In this sense, the performance of PHE actions and/or training with professionals in their work environments represents one of the main strategies for the adoption of safe practices in health work ${ }^{(5,19-20)}$. 
The use of DERs validated by specialists allows access to didactic materials that can favor significant learning in view of the knowledge and practices in health that expand the strategic actions for the promotion of health and safety at work. Studies mention that the use of educational games and videos represents a promising strategy for the development of knowledge, playing an important educational role in professional and personal training ${ }^{(7-8,1,1,16,20)}$.

The applicability of the knowledge provided by the DERs may contribute to the promotion of health and safety at work in the context of PHC, as they are used in PHE actions. These resources are intended to provoke a critical reflection on the aggravations of work to professionals in health units, reminding and reinforcing aspects that promote health, prevention of incidents, accidents and occupational diseases. These actions are considered opportunities to transform individual attitudes - so that they are protective in their uniqueness - and collective attitudes, for the health and safety at work of the entire team in PHC.

\section{$\square$ CONCLUSIONS}

Seven DERs were built and validated to address the promotion of health and safety at work by professionals working in PHC. Over four months, 850 hours were spent for the construction of the DERs in the development of all phases, which resulted in seven DERs with total visualization in 68 minutes and 38 seconds. In the validation of the content of the DERs, all products reached IVC $\geq 0.8$, being this the IVC desired for each domain and also in the global assessment of VECIH.

The fact that not all specialists invited to validate the content actually participated in this action is considered a limitation to this study, as well as the time for the return of the content evaluation. Therefore, these were the factors that guided the constitution of the Expert Committee. Another limitation was the difficulty to find studies in the scientific literature that correlated the production of educational resources in health and safety at work with PHC, as well as the discussion of these themes for content validation.

It is believed that the implementation of educational actions through PHE, using DERs that trigger a critical-reflective process on occupational risks to which professionals are exposed has the potential to achieve safe and effective behavior in preventing occupational accidents and diseases. The applicability of these DERs in a moment of PHE is conjectured, with an active methodology for the problematization in conversation with the PHC professionals. The need to increasingly encourage health professionals to reflect on their work is understood and, in particular, nurses, to develop actions that guarantee the consolidation and enhancement of the promotion of health and safety of workers in PHC.

\section{REFERENCES}

1. Stein $A T$, Ferri $(P$. Inovação e avanços em atenção primária no Brasil: novos desafios. Rev Bras Med Fam Comunidade. 2017;12(39):1-4. doi: https://doi. org/10.5712/rbmfc12(39) 1586

2. Ministério da Saúde (BR). Secretaria de Atenção à Saúde. Secretaria de Vigilância em Saúde. Saúde do trabalhador e da trabalhadora. Brasília: Ministério da Saúde; 2018 [cited 2019 Jul 12]. Cadernos de Atenção Básica, n. 41. Available from: http://189.28.128.100/dab/docs/portaldab/publicacoes/cadernoab_ saude_do_trabalhador.pdf

3. Arcanjo RVG, Chistovan BP, Braga ALS, Silvino ZR. Management of occupational risks of nursing in primary health care: a descriptive exploratory study. J Res Fundam Care online. 2018;10(2):351-7. doi: https://doi.org/10.9789/21755361.2018.v10i2.351-357

4. Antoniolli SAC. Recursos educativos digitais para a saúde e segurança no trabalho na atenção primária à saúde [dissertation]. Porto Alegre (RS): Universidade Federal de Ciências da Saúde de Porto Alegre; 2019 [cited 2019 Jul 2]. Available from: http://repositorio.ufcspa.edu.br/jspui/handle/123456789/761

5. Loro MM, BittencourtVLL, Zeitoune RCG. Assistance convergent research: nursing team sharing occupational risk knowledge and proposing interventions. Rev Min Enferm 2017;21:e-1044. doi: https://doi.org/10.5935/1415-2762.20170054

6. Cardoso ML, Costa PP, Costa DM, Xavier C, Souza RMP. The National Permanent Health Education Policy in Public Health Schools: reflections from practice. Cienc Saude Coletiva. 2017;22(5):1489-500. doi: https://doi. org/10.1590/1413-81232017225.33222016

7. Gonsales, P. Recursos educacionais abertos (REA) e novas práticas sociais. RECIIS Rev Electron Comun Inf Inov Saúde. 2016;10(1). doi: https://doi.org/10.29397/ reciis.v10i1.1078

8. Parulla CD, Galdino DM, Dal Pai D, Azzolin KO, Cogo ALP. Nursing assessment: the elaboration and development of a massive open online course. Rev Gaúcha Enferm. 2020;41(esp):e20190199. doi: https://doi. org/10.1590/1983-1447.2020.20190199

9. Alexandre NMC, Coluci MZO. Validade de conteúdo nos processos de construção e adaptação de instrumentos de medidas. Cienc Saude Coletiva. 2011;16(7):30618. doi: https://doi.org/10.1590/S1413-81232011000800006

10. Peres C, Silva RF, Barba PCSD. Desafios e potencialidades do processo de educação permanente em saúde. Trab Educ Saúde. 2016;14(3):783-801. doi: https://doi.org/10.1590/1981-7746-sol00016

11. Mesquita T M, Albuquerque RS, Bonfim AMA, Sales MLH, Santana MCCP, Ferreira AMV. Recurso educativo em primeiros socorros no processo ensinoaprendizagem em crianças de uma escola pública. Rev Ciência Plural. 2017 [cited 2019 Jul 15];3(1):35-50. Available from: http://periodicos.ufrn.br/rcp/ article/view/11464

12. Leite SS, Áfio AC, Carvalho LV, Silva JM, Almeida PC, Pagliuca LM. Construction and validation of an Educational Content Validation Instrument in Health. Rev Bras Enferm. 2018;71(4):1635-41. doi: https://doi. org/10.1590/0034-7167-2017-0648

13. Haynes SN, Richard DCS, Kubany ES. Content validity in psychological assessment: a functional approach to concepts and methods. Psychol Assess. 1995;7(3):238-47. doi: https://doi.org/10.1037/1040-3590.7.3.238 
14. Baldin N, Munhoz VER. Educação ambiental comunitária: uma experiência com a técnica de pesquisa snowball (Bola de Neve) Rev Eletrônica Mestr Educ Ambient. 2011 [cited 2019 Nov 13];27:46-60. Available from: https:// periodicos.furg.br/remea/article/view/3193/1855

15. Sousa MG, Oliveira EML, Coelho MMF, Miranda KCL, Henriques ACPT, Cabral RL. Validation of educational game for adolescents about the sexuality topic. J Res Fundam Care online. 2018;10(1):203-9. doi: http://doi.org/10.9789/21755361.2018.v10i1.203-209

16. Leite SS. Construção do roteiro do vídeo educativo para pessoas surdas sobre 0 uso do coito interrompido [dissertação]. Fortaleza (CE): Universidade Federal do Ceará; 2017 [cited 2019 0ct 10]. Available from: http://www.repositorio.ufc. $\mathrm{br} /$ handle/riufc/21888

17. Galindo-Neto NM, Alexandre ACS, Barros LM, Sá GGM, Carvalho KM, Caetano JA. Creation and validation of an educational video for deaf people about cardiopulmonary resuscitation. Rev Lat Am Enfermagem. 2019;27:e3130. doi: https://doi.org/10.1590/1518-8345.2765.3130

18. Moura IH, Silva AFR, Rocha AESH, Lima LHO, Moreira TMM, Silva ARV. Construction and validation of educational materials for the prevention of metabolic syndrome in adolescents. Rev Lat Am Enfermagem. 2017;25:e2934. doi: https://doi.org/10.1590/1518-8345.2024.2934
19. Silva APB, Brasileiro ME, Prado MA, Silva LCS, Andrade LZ, Lima WM, et al. Work accidents and their interfaces in the context of primary health care. Rev Enferm UFPE on line. 2017;11(12):5037-48. doi: http://doi. org/10.5205/1981-8963-v11i12a22543p5037-5048-2017

20. Silva DSJR, Duarte LR. Educação permanente em saúde. Rev Fac Ciênc Méd Sorocaba. 2015 [cited 2019 0ct 10];17:104-5. Available from: http://revistas. pucsp.br/index.php/RFCMS/article/view/23470/pdf

\section{Acknowledgments:}

To the Institutional Scientific Initiation Scholarship Program of the Fundação de Amparo a Pesquisa do Rio Grande do Sul (FAPERGS, ir Research Support Foundation of Rio Grande do Sul) for the scholarships granted through the Institutional Scientific Initiation Committee of theFederal University of Health Sciences of Porto Alegre (CPIC/UFCSPA)

\section{- Corresponding author:}

Silvana Aline Cordeiro Antoniolli

E-mail: linelli@bol.com.br

\section{Associate editor:}

